Pengaruh Islam Sebagai Salah Satu Penyebab Mundurnya Kerajaan Majapahit

\title{
Muhammad Chawari
}

Keywords: religion, archaeology, islam, hindu, east java, majapahit

\section{How to Cite:}

Chawari, M. (1993). Pengaruh Islam Sebagai Salah Satu Penyebab Mundurnya Kerajaan Majapahit. Berkala Arkeologi, 13(2), 18-27. https:/ / doi.org/10.30883/jba.v13i2.574

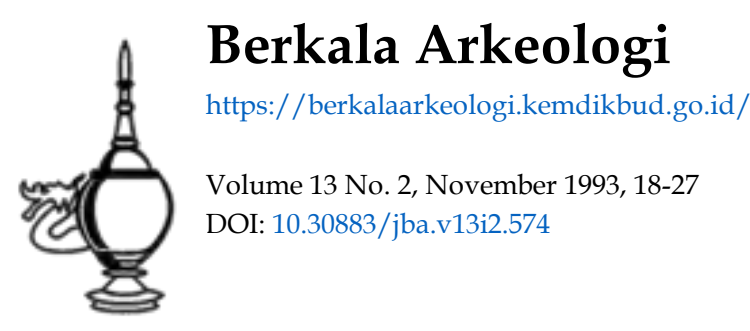




\title{
PENGARUH ISLAM SEBAGAI SALAH SATU PENYEBAB MUNDURNYA KERAJAAN MAJAPAHIT
}

\author{
Muhammad Chawari \\ (Balai Arkeologi Yogyakarta)
}

\section{PENDAHULUAN}

Pengaruh Islam yang dimaksud dalam tulisan ini adalah pengaruh dalam bidang sosial dan politik, bukan dalam bentuk pengaruh ajaran-ajarannya dalam mendekatkan diri kepada Tuhan sebagai al-khalik atau pencipta segala sesuatu. Di samping itu, pengaruh Islam di sini juga mencakup pengaruh etnik Tionghoa Islam dalam kaitannya dengan keberadaan Kerajaan Majapahit.

Majapahit adalah nama sebuah kerajaan yang besar dan kuat. Kerajaan ini sangat disegani baik oleh lawan maupun kawan dalam memperjuangkan eksistensinya. Majapahit mengalami jaman keemasannya di bawah pemerintahan Raja Hayam Wuruk dengan pembantu setianya Patih Hamangkubhumi Gajah Mada. Daerah taklukannyapun sangat luas, meliputi Sumatera, Kalimantan, Sulawesi, Kepulauan Maluku, dan Irian. Dengan perkataan lain daerah pengaruh kekuasaan Kerajaan Majapahit hampir seluas Negara Indonesia sekarang ini. Bahkan terdapat beberapa daerah taklukannya yang sekarang masuk wilayah negara tetangga dewasa ini.

Kerajaan yang besar dan kuat ini dalam perjalanan di kancah panggung sejarah kebudayaan Indonesia sering mengalami musibah. Musibah pertama yang menimpa terjadi pada tahun $1364 \mathrm{M}$, yaitu meninggalnya Patih Hamangkubhumi Gajah Mada. Disusul dengan musibah berikutnya yang terjadi 25 tahun sesudahnya, yaitu meninggalnya Raja Hayam Wuruk. Sepeninggal kedua pimpinan tersebut, Kerajaan Majapahit mulai menampakkan tanda-tanda kesuramannya. Kebesaran dan kejayaan Kerajaan Majapahit yang telah mencapai puncak keemasannya berangsur-angsur mulai surut. $\mathrm{Hal}$ ini juga disebabkan antara lain:

1. Sepeninggal Patih Gadjah Mada, kerajaan-kerajaan taklukan mulai mengangkat senjata dan tidak mau lagi mengakui keberadaan Kerajaan Majapahit. Hal ini disebabkan tidak ada lagi seorang pemimpin yang mampu mengendalikan roda pemerintahan kerajaan 
yang besar dan luas pengaruh serta kekuasaannya tersebut.

2. Pertentangan intern di dalam keluarga kerajaan yang disebabkan masing-masing berkeinginan menduduki jabatan tertinggi sebagai raja Majapahit. Sebagai contoh: Perang Paregreg antara Wikramawardhana (suami Kusumawardhani) dengan Bhre Wirabhumi. Bhre Wirabhumi berkeinginan menjadi orang nomor satu di Majapahit, tetapi tidak tercapai. Hal ini disebabkan karena Bhre Wirabhumi adalah anak Hayam Wuruk dengan istri selir.

3. Munculnya kekuatan baru dari sebelah timur, yaitu ekspansi Tiongkok di bawah Dinasti Ming.

4. Pengaruh Islam mulai menyusup ke dalam lingkungan Kerajaan Majapahit yang berlandaskan Hindu. Rapuhnya Kerajaan Majapahit dari dalam sendiri, yaitu dengan adanya pertentangan antar anggota keluarga, maka pengaruh Islam tersebut lebih mudah masuk ke dalam lingkungan kerajaan. Dengan demikian hal ini secara tidak langsung mempercepat mundurnya Kerajaan Majapahit.

\section{MASUKNYA PENGARUH ISLAM DAN PROSES ISLAMISASI}

Beberapa sarjana mengatakan bahwa masuknya pengaruh Islam ke Jawa dan proses Islamisasi adalah melalui beberapa cara. Secara umum beberapa cara tersebut antara lain melalui: perdagangan, perkawinan, kesenian, dan kepercayaan.

\section{Islam Mudah Masuk dan Berkembang di Masyarakat}

Sebelum masuknya pengaruh Islam sebagian besar penduduk daerah-daerah di Jawa Timur masih menganut kepercayaan yang berlandaskan pengaruh Hindu maupun Buddha. Selanjutnya dengan cepat pengaruh Islam masuk ke wilayah Kerajaan Majapahit melalui kota-kota pelabuhan. Hal ini disebabkan karena adanya pertentangan antar anggota keluarga kerajaan sepeninggal Raja Hayam Wuruk. Selain itu juga disebabkan karena masyarakat Islam telah menguasai perdagangan di pelabuhan-pelabuhan pantai Utara Jawa Timur. Mudahnya pengaruh Islam menyebar di lingkungan kerajaan disebabkan adanya 2 unsur sifat yang menguntungkan, yaitu:

Pertama; sifat Islam yang demokratis, yaitu di dalam Islam tidak dikenal adanya pembagian menurut kasta-kasta, tidak dibedakan antara kawula dengan raja, atau tidak dibedakan berdasarkan pangkat atau keturunan. Dengan demikian Islam cepat mendapat perhatian dari 
masyarakat luas. Kedua; sangat mudah untuk masuk ke dalam masyarakat Islam, karena tidak membutuhkan upacara-upacara tertentu. Dengan membaca "dua kalimah syahadat" mereka dapat masuk menjadi penganut Islam.

\section{Pengaruh Islam Masuk ke Jawa}

Berdasarkan berita-berita Arab dan Cina diketahui bahwa beberapa daerah di Indonesia sejak abad ke-7 telah dikunjungi oleh pedagang-pedagang Islam. Bahkan di daerah-daerah tersebut kemudian terbentuk koloni-koloni. Dengan adanya koloni-koloni tersebut, berdatangan para pedagang, yang menurut Tome Pires merupakan para saudagar muslim asing, terutama yang berasal dari Persi, Arab, dan India (Gujarat dan Benggala).

Salah satu daerah di Indonesia yang mula-mula mendapat pengaruh Islam adalah Malaka. Antara Malaka dengan kota-kota di pantai utara Jawa Timur terdapat hubungan perdagangan yang ramai. Dari Malaka itulah pengaruh Islam menyebar hampir ke segala jurusan di Kepulauan Indonesia sebelum tahun $1511 \mathrm{M}$.

Beberapa pelabuhan yang terdapat di pantai utara Jawa Timur antara lain: Canggu, Surabaya, Gresik, Sidhayu, Tuban, dan Pasuruhan. Pelabuhan-pelabuhan itu mengalami perkembangan ekonomi yang sangat pesat melalui perdagangan rempah-rempah dan hasil bumi dari daerah pedalaman. Dengan demikian muncullah penguasapenguasa daerah yang cukup kaya. Dengan alasan ekonomi itulah para penguasa daerah pesisir utara Jawa Timur menerima Islam sebagai pegangannya.

Daerah-daerah di pantai utara Jawa Timur yang mula-mula mendapat pengaruh Islam adalah Gresik dan Tuban. Hal ini tidak mengherankan, sebab Gresik pada waktu itu merupakan salah satu pelabuhan terpenting yang berfungsi mengeluarkan hasil-hasil usaha dalam lapangan ekonomi yang berasal dari daerah pedalaman Majapahit. Salah satu faktor yang menguntungkan dalam perkembangan kota-kota pelabuhan tersebut ialah letak geografisnya. Letak geografis ini sangat penting artinya karena pelabuhan-pelabuhan tersebut terletak tidak jauh dari Semenanjung Malaka, yang telah lebih dahulu mendapat pengaruh Islam.

Bukti-bukti pengaruh Islam telah masuk ke Jawa sesudah abad ke-7 (karena pada abad ke-7 itu pengaruh Islam baru memasuki Malaka dan mungkin juga Sumatera Utara), yaitu:

a. Di daerah Leran (Gresik) didapatkan adanya nisan kubur tertua di 
Jawa yang berangka tahun $1082 \mathrm{M}$. Pada salah satu bidang permukaan nisan tersebut terdapat tulisan Arab bergaya Kufi. Nama yang tercantum dalam tulisan itu adalah Fatimah binti Maimun bin Hibatallah. Menurut J.P. Moquette tokoh tersebut wafat pada tahun 1102 M, sedangkan menurut $P$. Rafaisse tahun 1082 M. Meskipun nisan kubur ini tidak menunjukkan adanya kerajaan bercorak Islam, tetapi jelas memberikan bukti tentang adanya masyarakat muslim yang mungkin kebanyakan dari golongan pedagang. Mereka diterima bertempat tinggal di Leran (pesisir Gresik) oleh masyarakat yang sebagian masih dalam kekuasaan kerajaan yang bercorak Indonesia-Hindu menjelang Kerajaan Kadiri, demi kepentingan perdagangan.

b. Masih di daerah Gresik, didapatkan kompleks makam yang terkenal dengan nama Makam Maulana Malik Ibrahim. Tokoh ini diperkirakan berasal dari Kashan (Iran) berdasarkan hasil pembacaan J.P. Moquette pada baris kelima teks utama pada prasasti makamnya. Tahun meninggal adalah tahun $822 \mathrm{H}$ atau $1419 \mathrm{M}$. Peninggalan Makam Maulana Malik Ibrahim dapat dianggap sebagai suatu bukti adanya hubungan dengan Samudera Pasai, bahkan dengan Gujarat. $\mathrm{Hal}$ ini didasarkan pada bentuk maupun cara menuliskan huruf-huruf Arab, penggunaan ayat 255 surat Al-Baqarah atau ayat Kursi pada bingkai nisan makam, dan bahan batu pualam yang sejenis, yang menunjukkan persamaan dengan beberapa makam yang ada di Samudera Pasai dan Cambay-Gujarat. Berdasarkan persamaanpersamaan di antara kubur-kubur tersebut, maka J.P. Moquette berpendapat bahwa nisan- nisan tersebut dibuat dalam satu pabrik, yaitu yang ada di Cambay. Dari kedua hal tersebut di atas, dapat dikemukakan: Pertama; sudah ada hubungan yang terus berlangsung dalam hal pelayaran dan perdagangan antara GujaratSamudera Pasai dan Pesisir Utara Jawa Timur pada awal abad ke15. Kedua; Makam Maulana Malik Ibrahim dapat memberikan bukti bahwa di Gresik pada abad ke-15 sudah terdapat sekelompok masyarakat muslim, yang di antaranya merupakan pemuka masyarakat. Khusus penokohan Maulana Malik Ibrahim yang dihubungkan dengan pemuka masyarakat dapat dilihat pada nisannya. Berdasarkan kata-kata yang menggambarkan kedudukan dan statusnya, yaitu yang tercantum pada baris ke-4 dan 5 , terdapat 6 istilah yang masing artinya sbb:

- Kebanggaan orang-orang keluarga istana

- Tiang kekuatan bagi sultan-sultan dan menteri-menteri 
- Pecinta orang-orang miskin dan papa

- Saksi yang diberkahi bagi keadilan

- Bukti bagi kerajaan dan agama

- Nama Malik Ibrahim itu sendiri berarti Raja/Penguasa Ibrahim

Dengan demikian sebutan-sebutan tersebut mencerminkan kebesaran dan keagungan individu serta status Ibrahim di kalangan masyarakat. la juga merupakan raja yang saleh dan sangat populer di negeri Gresik.

c. Di Tralaya dan Trowulan (Mojokerto) terdapat sebuah kompleks pemakaman Islam kuna yang letaknya tidak jauh dari kompleks bekas Kraton Majapahit. Nisan-nisan tersebut berasal dari sekitar abad ke-14 sampai abad ke-16, bahkan terdapat pula sebuah nisan yang berasal dari abad ke-17. Satu hal yang menarik perhatian yaitu adanya 2 buah angka tahun yang masing-masing berasal dari situs Trowulan dan situs Tralaya. Angka tahun tersebut yaitu tahun 1281 $M$ dan $1282 \mathrm{M}$. Jika dilihat dari usia, maka kedua angka tahun tersebut berasal dari masa sebelum berdirinya Kerajaan Majapahit.

Dengan demikian maka pada tahun-tahun seperti tersebut di atas hampir seluruh daerah pantai utara Jawa Timur sedikit banyak telah terkena pengaruh kedatangan Islam.

\section{PENGARUH ISLAM DI DALAM KERAJAAN MAJAPAHIT}

\section{Dari Segi Kehidupan Sosial Budaya}

Sepeninggal Patih Gajah Mada kehidupan para pembesar Kerajaan Majapahit yang serba mewah dan sejahtera menjadi agak lengah. Raja Wikramawardhana alias Hyang Wisesa kawin dengan putri Cina. Dari perkawinan itu lahirlah Arya Damar atau Swan Liong yang kemudian menjadi kapten Cina dan merangkap adipati di Palembang. Kelihatannya perkawinan antara Wikramawardhana dengan putri Cina itu merupakan hal yang kecil, tetapi pada hakekatnya menghasilkan benih-benih yang nantinya akan merongrong kewibawaan Kerajaan Majapahit itu sendiri.

Selain Wikramawardhana, Raja Kertabhumi juga mengawini putri Cina. Dari perkawinan ini lahirlah Raden Patah atau Jin Bun yang pada tahun $1478 \mathrm{M}$ telah berumur kurang lebih 23 tahun. Dari contoh dua perkawinan di atas, dapat diasumsikan bahwa mungkin masih banyak pembesar Majapahit yang mengawini putri Cina, hanya saja tidak atau belum tercatat dalam sejarah. 
Asal mula terjadinya perkawinan antara para pembesar Kerajaan Majapahit dengan putri-putri Cina ialah karena hampir di seluruh kotakota pelabuhan di pantai utara Jawa (Jawa Tengah maupun Jawa Timur) telah terbentuk masyarakat Tionghoa Islam. Hampir semua kota pelabuhan di pantai utara Jawa, yang merupakan tempat perdagangan yang ramai dan urat nadi perekonomian Kerajaan Majapahit, telah dikuasai atau dimonopoli oleh orang-orang Tionghoa Islam yang datang dari Yunan. Sesuai dengan perintah dari daerah asalnya, mereka mengadakan hubungan politik dan dagang dengan negara-negara tempat mereka menetap. Sebenarnya sebelum kedatangan orangorang Tionghoa Islam ini, tempat-tempat tersebut telah dimonopoli lebih dahulu oleh para pedagang Majapahit. Dengan adanya masyarakat Tionghoa Islam di kota-kota pelabuhan di pantai utara Jawa sumber perekonomian Majapahit tersumbat. Kerajaan Majapahit telah terkepung oleh orang-orang Tionghoa Islam dari arah laut.

\section{Dari Segi Pemerintahan}

Hubungan antara Kerajaan Majapahit dengan Tiongkok dibuka secara resmi pada tahun $1424 \mathrm{M}$, yaitu pada masa pemerintahan Prabu Wikramawardhana atau Hyang Wisesa yaitu ayah Arya Damar atau Swan Liong. Hubungan itu ditandai dengan pengiriman duta besar Tiongkok yang pertama di kota Majapahit, dan masa jabatan duta besar itu berakhir pada tahun $1449 \mathrm{M}$. Kemudian pada tahun $1475 \mathrm{M}$ datang duta besar Tiongkok yang kedua ke Kerajaan Majapahit. Duta besar itu bernama Raden Kusen atau Kin San. la diperintahkan untuk bertindak sebagai mata-mata demi kepentingan masyarakat Tionghoa Islam. la diharapkan dapat memberikan segala keterangan mengenai seluk beluk dalam keraton Majapahit yang berguna bagi masyarakat Tionghoa Islam. Raden Kusen atau Kin San yang memang sudah mendapat didikan matang dari Arya Damar atau Swan Liong berhasil menggembirakan hati Raja Kertabhumi. Dengan demikian memang terdapat maksud tertentu dari pihak masyarakat Tionghoa Islam untuk merobohkan kekuasaan Majapahit, baik dari dalam maupun dari luar.

Pangkat membawa kekuasaan, kekuasaan membawa atau memberi kesempatan untuk memperoleh pengikut atau memperoleh sesuatu yang diinginkan. Untuk memperoleh derajat yang tinggi dalam masyarakat Hindu-Jawa Majapahit, para pemuka Tionghoa Islam harus pandai melayani para pembesar terutama raja Majapahit sebagai pembesar tertinggi. Selain Raden Kusen masih ada lagi seorang Cina yang dapar menggembirakan salah seorang pembesar Kerajaan 
Majapahit yaitu Gan Eng Cu yang juga berpangkat kapten Cina. Karena kepandaian Gan Eng Cu melayani raja Majapahit, ia diberi gelar Arya oleh Rani Suhita dan sekaligus memakai nama jawa. Gelar dan nama lengkapnya adalah Tumenggung Wilatikta Arya Teja. Kemudian Raden Patah atau Jin Bun mendapat gelar pangeran. Dengan gelar itu mereka memperoleh kehormatan di kalangan masyarakat Hindu-Jawa Majapahit. Merekapun lebih mudah memperoleh pengikut di antara para pegawai kerajaan dan rakyat Majapahit.

\section{Akibat Masuknya Islam di Kerajaan Majapahit}

Pemberian gelar oleh raja kepada seseorang mengandung pengertian bahwa seseorang karena jasa-jasanya kepada raja atau negara memperoleh hak-hak yang bertalian dengan gelar yang diberikan untuk dapat dinikmati seperlunya. Pembukaan hutan belantara di daerah Bintara oleh Raden Patah atau Jin Bun pada hakekatnya adalah merupakan persiapan untuk merobohkan kekuasaan syah Majapahit. Perbuatan Raden Patah pada dasarnya merupakan kegiatan rahasia untuk melawan kekuasaan yang syah dari Kerajaan Majapahit dan tidak ada yang mencurigai perbuatan tersebut kecuali kelompok tertentu.

Meskipun Arya Damar dan Raden Patah itu putera raja Majapahit, tetapi mereka bekerja demi kepentingan masyarakat Tionghoa Islam. Arya Damar dan Raden Patah memihak golongan Tionghoa Islam, setia menurut garis keturunan ibu dan bukan garis keturunan ayah walaupun sebagai seorang raja. Dengan demikian seolah-olah tidak ada hubungan kekeluargaan dengan raja Majapahit.

Pada sekitar tahun 1478 M Raden Patah memimpin tentara Demak yang telah dipersiapkan sebelumnya untuk menyerbu keraton Majapahit secara mendadak. Raja Majapahit tidak menduga serangan tersebut, sehingga tidak ada persiapan apapun dari pihak Majapahit. Dengan mudah Raden Patah berhasil menawan Raja Kertabhumi dan mengangkutnya ke Demak.

Selain itu menurut Babad Tanah Jawi, Demak yang semula bernama Bintara tumbuh menjadi sebuah kekuatan tersendiri. Dengan kekuatannya tersebut, Adipati Terung (yang telah masuk Islam) karena condong ke Majapahit ikut ditawan bersama-sama dengan raja Majapahit terakhir dan dibawa ke Demak. Raja Majapahit terakhir yang sudah lanjut usia itu telah masuk Islam atas bujukan Raden Kusen. Dengan demikian di kalangan atas telah terjadi perdamaian. Hal ini 
dapat dibuktikan bahwa setelah raja Majapahit dan Adipati Terung sampai di Demak, mereka tidak dianggap sebagai musuh lagi. Bahkan raja Majapahit tersebut hidup di bawah perlindungan puteranya sendiri sampai meninggal.

Dengan demikian keruntuhan Kerajaan Majapahit diakibatkan adanya serangan secara mendadak oleh Raden Patah yang berkedudukan di Bintara (Demak). Namun demikian beberapa ahli mengatakan bahwa keruntuhan Kerajaan Majapahit tidak perlu dihubungkan dengan serangan orang-orang Muslim, melainkan karena adanya serangan dari kerajaan lain yang bercorak Hindu juga, yaitu Kerajaan Kadiri dengan rajanya Girindrawarddhana Dyah Ranawijaya. Pada waktu itu raja Majapahit adalah Bhre Kertabhumi. Serangan tersebut mengakibatkan tewasnya raja Majapahit di Kedatonnya. Ranawijaya sebagai pewaris yang syah berhasil merebut kekuasaan Majapahit dari tangan Kertabhumi. Menurut Hasan Dja'far keruntuhan Kerajaan Majapahit terjadi pada tahun 1400 Ç atau $1478 \mathrm{M}$ dengan candra sengkala sirna - ilang - kertaning - bumi. Tahun tersebut seharusnya diterjemahkan sebagai peristiwa perebutan kekuasaan atas tahta Kerajaan Majapahit oleh Girindrawarddhana Dyah Ranawijaya terhadap Bhre Kertabhumi.

Dari kedua pendapat di atas timbullah suatu pertanyaan menarik yang sulit dijawab, yaitu: Apakah orang-orang Muslim berperan dalam perebutan kekuasaan itu, serta apakah dampaknya bagi hubungan antara orang-orang Muslim dengan orang- orang Hindu di Jawa.

\section{KESIMPULAN}

Kerajaan Majapahit mula-mula merupakan kerajaan yang besar dan kuat. Keadaan seperti itu ternyata tidak dapat dipertahankan dalam waktu yang lama. Setelah ditinggalkan oleh Raja Hayam Wuruk dan Patih Gajah Mada, kerajaan tersebut mulai mengalami kemunduran. Dengan meninggalnya kedua pimpinan tersebut, maka raja-raja di daerah taklukan mulai mengangkat senjata terhadap Majapahit. Pertentangan dari dalam, yaitu perebutan tahta kerajaan dan munculnya ekspansi Tiongkok dari Dinasti Ming mempercepat kemunduran Kerajaan Majapahit. Meskipun demikian, sebab yang paling pokok adalah adanya pengaruh Islam yang telah masuk di dalam keraton Majapahit serta menguasai perdagangan di pelabuhanpelabuhan pantai utara Jawa (baik Jawa Tengah maupun Jawa Timur). 
Pengaruh Islam itu telah mempengaruhi salah seorang putera raja yang ibunya berasal dari keturunan Cina muslim. Putera raja tersebut adalah Raden Patah atau Jin Bun. Beliau dengan pengikutnya yang memang telah dipersiapkan sebelumnya di daerah Bintara kemudian menyerang Kerajaan Majapahit. Penyerangan itu dilakukan antara lain karena tidak senang melihat Majapahit yang berlandaskan Hindu, walaupun sebenarnya ia sendiri merupakan salah seorang putera keturunan Majapahit juga.

\section{KEPUSTAKAAN}

Gibb, H.A.R., 1960, Islam Dalam Lintasan Sejarah. Jakarta: Bhratara.

Hamka., 1961, Sejarah Umat Islam IV. Bukittinggi-Jakarta: N.V. Nusantara,

Hasan Dja'far., 1978, Girindrawarddhana Beberapa Masalah Majapahit Akhir. Jakarta: Yayasan Dana Pendidikan Budhis Nalanda, cetakan kedua.

Yamin, H.M., 1962, Tata Negara Majapahit III. Jakarta: Yayasan Prapanca.

Olthof, W.L., 1941, Babad Tanah Jawi Wiwit Saking Nabi Adam Doemoegi ing Tahun 1647. Leiden: sGravenhage.

Slamet Muljana, 1965, Menuju Puncak Kemegahan (Sejarah Kerajaan Majapahit). Jakarta: P.N. Balai Pustaka.

Slamet Muljana, 1968, Runtuhnya Kerajaan Hindu Jawa dan Timbulnya Negara- negara Islam di Nusantara. Jakarta: Bhratara.

Subardi; Harsojo; dan Mahmud Yunus., 1961, Pengantar Sejarah dan Ajaran Islam. Bandung-Jakarta: N.V. Ganaco, cetakan ketiga. 
Uka Tjandrasasmita, 1993, Majapahit Dan Kedatangan Islam Serta Prosesnya, 700 Tahun Majapahit (1293 - 1993) Suatu Bunga Rampai. Edisi Kedua. Surabaya: CV. Wisnu Murti. 